\title{
Apakah Belanja Modal dan Belanja Sosial Meningkatkan Pertumbuhan Ekonomi? Bukti Data Panel di Indonesia
}

\author{
Asnawi ${ }^{1 *}$ \\ 1* Fakultas Ekonomi dan Bisnis, Universitas Malikussaleh, Kota Lhokseumawe, \\ Provinsi Aceh, Indonesia.
}

\begin{abstract}
Abstrak. Penelitian ini menganalisis pengaruh belanja modal dan belanja sosial terhadap pertumbuban ekonomi daerah di Indonesia. Menggunakan data panel 24 provinsi selama periode 2005-2018, data dianalisis menggunakan peralatan ekonometrik regresi panel pendekatan fixed effect. Penelitian menemukan bahwa belanja modal dan belanja sosial secara signifikan dapat meningkatkan pertumbuban ekonomi. Semakin besar realisasi anggaran daerah untuk. kedua belanja tersebut semakin tinggi pertumbuban ekonomi.
\end{abstract}

Kata kunci: Pertumbuban Ekonomi; Belanja Modal; Belanja Sosial; Regresi Panel.

\begin{abstract}
This study analyzes the effect of capital and social spending on regional economic growth in Indonesia. Using panel data from 24 provinces during the period 2005-2018, the data were analyzed using a panel regression econometric tool with a fixed effect approach. The study pointed out that capital and social spending can significantly increase economic growth. The greater the realization of the local government budget for these two expenditures, the higher the economic growth.
\end{abstract}

Keywords: Economic Growth; Capital Spending; Social Spending; Panel Regression. 


\section{Pendahuluan}

Pembangunan ekonomi yang dilakukan pemerintah melalui sejumlah program pembangunan diharapkan dapat meningkatkan pendapatan masyarakat. Di tingkat daerah, instrumen kebijakan yang biasanya digunakan pemerintah dalam mendukung program pembangunan ini adalah anggaran publik, terutama dalam bentuk belanja pemerintah daerah. Belanja pemerintah berdampak pada perubahan nilai barang dan jasa yang dihasilkan dalam suatu perekonomian (Pula \& Elshani, 2018), dan memiliki peran penting dalam mendukung pertumbuhan ekonomi baik dalam jangka pendek maupun jangka panjang (Gupta et al., 2005; Bose et al., 2007). Efek belanja terhadap peningkatan pendapatan masyarakat terjadi melalui dampaknya pada penyediaan infrastruktur publik guna mendukung kegiatan ekonomi masyarakat. Selain itu, belanja pemerintah di suatu daerah juga dapat mendorong konsumsi, dan konsumsi merupakan faktor penentu pertumbuhan itu sendiri (Ebaid \& Bahari, 2019).

Belanja yang dimaksudkan dalam kajian ini adalah belanja modal dan belanja sosial. Belanja modal adalah belanja pemerintah daerah yang diperuntukan untuk pengadaan barang-barang modal termasuk pembangunan instrastruktur fisik guna meningkatkan kegiatan ekonomi masyarakat (Amri, 2014). Sedangkan belanja sosial meliputi alokasi belanja pemerintah yang dimaksudkan untuk mendanai belanja sosial, termasuk dalam bentuk hibah dan bantuan bagi masyarakat (Nazamudin \& Amri, 2020). Alokasi anggaran publik dalam dua jenis belanja ini diharapkan mampu mendorong kegiatan ekonomi sehingga berdampak positif bagi pertumbuhan ekonomi dan peningkatan kesejahteraan masyarakat.

Selama ini, bukti empiris mengenai keterkaitan pertumbuhan ekonomi dan belanja pemerintah telah banyak diungkapkan para peneliti ekonomi (Guillaumont \& Kpodar, 2011; Matthew \& Udom, 2015; Obayori, 2016). Namun temuan mereka tentang arah dan signifikansi hubungan kedua variabel ini masih memberikan kesimpulan yang beragam, sehingga efektivitas belanja dalam mendorong pertumbuhan masih menjadi pertanyaan terbuka. Berkaitan dengan belanja modal misalnya, sejumlah peneliti membuktikan bahwa pengaruh belanja ini terhadap pertumbuhan adalah positif dan signifikan (Akhmad et al., 2013; Morozumi \& Veiga, 2016), negatif signifikan (Gregoriou \& Ghosh, 2009; Radulescu et al., 2019), dan negatif tidak signifikan (Modebe et al., 2012). Bahkan terdapat penelitian yang mengungkapkan bahwa pengaruh belanja modal terhadap pertumbuhan ekonomi bisa positif dan negatif, tergantung pada sejumlah variabel ekonomi lainnya (Lukman et al., 2018).

Arah dan signifikan pengaruh belanja sosial terhadap pertumbuhan ekonomi juga masih kontroversial dikalangan peneliti. Alokasi pengeluaran pemerintah dalam bentuk belanja sosial secara signifikan dapat meningkatan pertumbuhan ekonomi dan memperbaiki kesejahteraan masyarakat (Amri, 2020). Sebelumnya, kajian yang dilakukan Mayer et al. (2016) juga membuktikan bahwa belanja sosial meningkatkan pendapatan dan memperbaiki masyarakat. Bertolak belakang dengan dua temuan tersebut, hasil penelitian Connolly \& Li (2016) menemukan bahwa belanja sosial memiliki pengaruh terbalik terhadap pertumbuhan. Pengaruh tersebut signifikan yang berarti peningkatan alokasi anggaran publik untuk membiayai belanja sosial secara signifikan berdampak pada penurunan pertumbuhan. Pengaruh terbalik belanja sosial terhadap pertumbuhan disebabkan dampaknya pada keinginan masyarakat dalam berusaha. Peningkatan belanja sosial mengurangi keinginan masyarakat dalam berwirausaha, dan kondisi ini juga berpengaruh negatif terhadap perkembangan bisnis (Solomon et al., 2021). Temuan kontroversial lainnya berkaitan dengan pengaruh belanja sosial terhadap pertumbuhan dibuktikan oleh Im et al. (2011) dalam penelitian mereka menggunakan data negara berkembang dan negara maju menyimpulkan bahwa belanja sosial berpengaruh positif terhadap pertumbuhan ekonomi di negara berkembang, sebaliknya di negara maju, pengaruh tersebut negatif.

Seperti dijelaskan di atas, hasil kajian empiris peneliti terdahulu mengenai arah dan signifikansi keterkaitan antara belanja modal dan belanja sosial dengan pertumbuhan 
ekonomi dan kesejahteraan masyarakat masih menjadi pertanyaan terbuka. Hingga saat ini belum ada kesimpulan yang fix mengenai kemampuan kedua jenis belanja tersebut dalam mendorong pertumbuhan. Dengan kata lain, arah dan signifikansi hubungan antara variabelvariabel ini masih menjadi pertanyaan terbuka dan masih perlu diteliti lebih lanjut. Karena itu, penelitian ini berupaya mengungkapkan bukti empiris mengenai kemampuan belanja modal dan belanja sosial dalam meningkatkan pendapatan masyarakat dalam kontek perekonomian Indonesia. Kajian ini sangat relevan mengingat pertumbuhan ekonomi daerah di Indonesia relatif berbeda satu sama lain, dan di lain pihak realisasi anggaran pemerintah daerah dalam bentuk belanja modal dan belanja sosial juga berbeda berdasarkan daerah.

Secara sistematis, artikel ini disusun dalam empat bagian. Bagian kedua adalah data dan model analisis, menjelaskan tentang data yang digunakan serta model ekonometrika yang diterapkan dalam menganalisis hubungan antar variabel. Bagian ketiga adalah hasil dan pembahasan, menyajikan informasi mengenai statistik deskriptif masing-masing variabel dan hasil estimasi pengaruh belanja terhadap pertumbuhan serta pembahasannya. Bagian terakhir adalah kesimpulan dan implikasi.

\section{Data dan Model Analisis}

Penelitian menggunakan data panel yakni gabungan antara data runut waktu (time series data) selama periode tahun 2005-2018, dengan data silang (cross-section data) dari 24 provinsi di Indonesia. Seluruh data bersumber dari BPS Indonesia. Data tersebut terdiri dari pendapatan per kapita, belanja modal dan belanja sosial. Pertumbuhan ekonomi diroxi dari PDRB per kapita berdasarkan harga konstan tahun 2000. Penggunaan PDRB per kapita sebagai pendekatan dalam mengukur pertumbuhan ekonomi juga dilakukan oleh sejumlah peneliti (Ebaid \& Bahari, 2019; Amri et al., 2019; Hasyim et al., 2019; Amri \& Adi, 2021). Belanja modal adalah realisasi belanja modal diukur dengan satuan rupiah per kapita. Belanja sosial (BHS) yang dimaksudkan dalam hal ini adalah realisasi belanja hibah dan bantuan sosial diukur dengan satuan rupiah per kapita.

Dikarenakan data yang dioperasionalkan dalam kajian ini berbentuk panel data yakni gabungan antara data runut waktu dan data silang, maka secara matematik keterkaitan antara pertumbuhan ekonomi dengan belanja modal dan belanja sosial dinyatakan dalam persamaan 1.

$\mathrm{PDRB}_{\mathrm{it}}=\mathrm{f}\left(\mathrm{BM}_{\mathrm{it}}, \mathrm{BS}_{\mathrm{it}}\right)$

Berdasarkan model di atas maka untuk menguji pengaruh kedua jenis belanja pemerintah terhadap pertumbuhan ekonomi digunakan regresi panel dengan dua variabel independen. Namun, setiap variabel terlebih dahulu ditransformasi dalam bentuk logaritma. Ini dimaksudkan agar koefisien estimasi yang diperoleh dapat diartikan sebagai elastisitas variabel independen (Chen et al., 2019). Sehingga persamaan 1 tersebut ditransformasi dalam bentuk regresi panel seperti dalam persamaan 2 .

$\log \mathrm{PDRB}_{\mathrm{it}}=\alpha+\beta_{1} \log \mathrm{BM}_{\mathrm{it}}+\beta_{2} \log \mathrm{BS}_{\mathrm{it}}+\mu_{\mathrm{it}}$

Dimana, $\log \mathrm{PDRB}_{\text {it }} \quad \log \mathrm{BM}_{\mathrm{it}}$, dan $\log \mathrm{BS}_{\mathrm{it}}$, masing-masing adalah nilai logaritma PDRB per kapita (sebagai proxi dari pertumbuhan ekonomi), belanja modal dan belanja sosial di provinsi $i$ pada periode tahun t. i merepresentasikan provinsi ke-i $(1,2, \ldots$ 28) dan $\mathrm{t}$ adalah periode $(2005,2006, \ldots$ 2018). $\alpha$ adalah konstanta, $\beta_{1}$ dan $\beta_{2}$ masing-masing merupakan koefisien estimasi $\log \mathrm{BM}_{\mathrm{it}}$ dan $\log \mathrm{BS}_{\mathrm{it}}$. Terakhir $\mu_{\text {it }}$ merepresentasikan error term.

Penggunaan regresi panel sebagai model analisis data menawarkan tiga alternatif pilihan pendekatan terdiri dari common effect model, fixed effect model dan random effect model. Dalam kajian ini, pendekatan yang digunakan adalah fixedeffect model. Hal ini didasarkan pada Chow-test yang menghasillkan p-value cross section $\mathrm{F}$ sebesar $0,000<0,05$, dan Haussman test yang menghasilkan p-value cross section $\mathrm{X}^{2}$ sebesar 0.000 $<0,05$. 


\section{Hasil dan Pembahasan}

Sebagaimana dijelaskan sebelumnya, data yang dioperasionalkan dalam penelitian ini terdiri dari pertumbuhan ekonomi yang diproxi dari PDRB per kapita, realisasi belanja modal dan belanja sosial. Realisasi kedua jenis belanja ini diukur dengan satuan rupiah per kapita. Seluruh data ditransformasi dalam bentuk logaritma. Hasil statistik deskriptif dan matrik korelasi antar variabel seperti dalam Tabel 1.

Tabel 1. Statistik Deskriptif danMatrik Korelasi

\begin{tabular}{|l|c|c|c|}
\hline & \multicolumn{3}{|c|}{ Statistik Deskriptif } \\
\hline & LogPDRB & LogBM & logBS \\
\hline Mean & 8.945 & 11.513 & 11.019 \\
\hline Median & 8.914 & 11.554 & 11.618 \\
\hline Maximum & 10.251 & 13.757 & 12.914 \\
\hline Minimum & 7.750 & 9.049 & 5.759 \\
\hline Observations & 336 & 336 & 336 \\
\hline \multicolumn{4}{|c|}{ Matrik Korelasi } \\
\hline $\log$ PDRB & 1 & 1 & 1 \\
\hline $\operatorname{logBM}$ & 0.455 & 0.548 & \\
\hline $\operatorname{logBS}$ & 0.474 &
\end{tabular}

Sumber: Data Sekunder (Diolah), 2022

Tabel 1 di atas memperlihatkan nilai logaritma masing-masing variabel. Untuk variabel PDRB per kapita, nilai tertinggi sebesar 10,251. Sebaliknya nilai terendah sebesar 7,750 dengan rata-rata sebesar 8,945. Selanjutnya belanja modal $(\log B M)$ dan belanja sosial $1(\log B S)$, nilai tertinggi untuk untuk kedua variabel ini masing-masing sebesar 13,757 dan 12,914. Selanjutnya, nilai rata-rata diperoleh sebesar 9,019 untuk belanja modal dan sebesar 5,759 untuk belanja sosial. Hal ini mengindikasikan bahwa secara rata-rata, alokasi anggaran daerah untuk membiayai belanja modal lebih besar dibandingkan dengan belanja sosial.

Tabel 1 di atas juga memperlihatkan koefisien korelasi antar variabel. Korelasi antara belanja modal (logBM) dan belanja sosial (logBS) sebesar 0,548. Angka ini berada pada interval 0,40-0,60 yang berarti hubungan antara kedua variabel tidak erat dan tidak lemah. Namun hubungan ini positif, yang mengindikasikan bahwa terdapat hubungan searah antara belanja modal dan belanja sosial. Peningkatan realisasi anggaran daerah untuk membiayai belanja modal diiringi dengan peningkatan realisasi belanja sosial. Dengan kata lain, di daerah dengan belanja modal relatif lebih besar, maka belanja sosial di daerah tersebut juga akan lebih besar dibandingkan daerah lain dengan belanja modal relatif lebih kecil. Sebaliknya, penurunan belanja modal juga seiring dengan penurunan alokasi belanja sosial.

Seperti ditunjukkan dalam Tabel 1, koefisien korelasi antara kedua jenis belanja tersebut dengan PDRB per kapita juga menunjukkan angka positif. Hal ini menjadi bukti statistik bahwa kenaikan pertumbuhan ekonomi di suatu daerah berhubungan positif dengan realisasi belanja modal dan belanja sosial. Dengan kata lain, perubahan realisasi belanja ini memiliki hubungan searah dengan perubahan pendapatan masyarakat.

Analisis terhadap pengaruh belanja modal dan belanja sosial terhadap pertumbuhan ekonomi menggunakan regresi panel pendekatan fixedeffect. Pendekatan fixed-effect diyakini mampu memberikan hasil estimasi lebih baik dibandingkan dengan dua pendekatan lainnya (common-effect dan random-effect). Justifikasi ini didasarkan pada hasil Chow test dan Hausman test yang telah dijelaskan sebelumnya. Hasil regresi panel menggunakan pendekatan fixed effect seperti ditunjukkan dalam Tabel 2. 
Tabel 2. Hasil regresi panel pendekatan fixed-effect

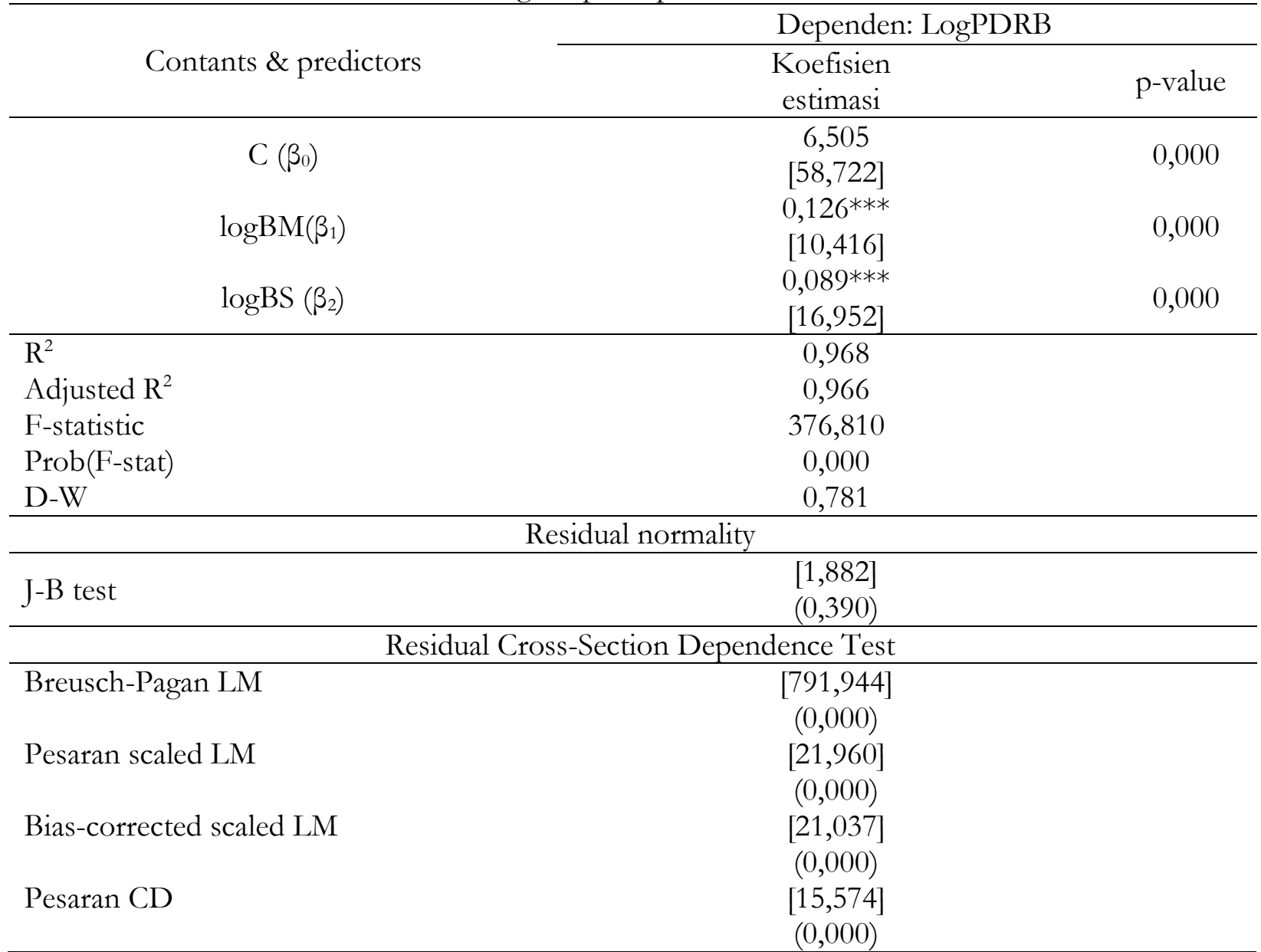

Sumber: Data Sekunder (Diolah), 2022.

Angka dalam tanda [ ] adalah nilai t statistik, dan dalam ( ) adalah nilai p-value.

Berdasarkan Tabel di atas dapat dilihat bahwa belanja modal berpengaruh positif dan signifikan terhadap pendapatan per kapita $\left(\beta_{1}=\right.$ $0,126 ; \mathrm{p}$-value $<0,05)$. Peningkatan belanja modal sebesar $1 \%$ mendorong pertumbuhan ekonomi sebesar $0,126 \%$ dengan asumsi tidak terdapat perubahan pada alokasi belanja sosial. Semakin besar realisasi belanja daerah dalam bentuk belanja modal seperti pembangunan infrastruktur publik misalnya, semakin tinggi pertumbuhan ekonomi. Sebaliknya, penurunan belanja ini berdampak pada penurunan pendapatan. Belanja modal pada dasarnya adalah alokasi belanja publik yang dimaksudkan untuk pengadaan barang-barang modal termasuk pembangunan infrastruktur publik. Peningkatan belanja ini dapat mendorong peningkatan aktivitas ekonomi yang pada gilirannya meningkatkan pertumbuhan pendapatan (Matthew \& Udom, 2015). Temuan ini sejalan dengan hasil penelitian Muda dan Hutapea (2018) menggunakan data panel kabupaten kota di Sumatera Utara dan Jawa Barat yang juga membuktikan bahwa belanja modal secara signifikan dapat meningkatkan pertumbuhan ekonomi.

Belanja sosial juga secara positif dan signifikan dapat mendorong peningkatan pertumbuhan ekonomi $\quad\left(\beta_{2}=0,089 ; \mathrm{p}\right.$-value $\left.<0,05\right)$. Peningkatan alokasi anggaran pemerintah daerah untuk membiayai belanja sosial berdampak signifikan pada peningkatan pendapatan masyarakat. Sebaliknya, penurunan belanja ini juga secara signifikan menurunkan pendapatan. Belanja sosial antara lain diwujudkan dalam bentuk bantuan sosial kepada masyarakat, baik berupa cash transfer maupun barang berwujud. Semakin besar realisasi belanja sosial di suatu daerah, semakin tinggi pendapatan dan kesejahteraan masyarakat di daerah yang bersangkutan. Alokasi belanja sosial dalam bentuk bantuan tunai misalnya, berdampak baik pada konsumsi masyarakat 
yang pada gilirannya meningkatkan kesejahteraan. Demikian pula halnya dengan alokasi dana hibah dan bantuan sosial untuk dunia usaha, tidak hanya dapat berdampak langsung pada kesejahteraan penerima bantuan, tetapi juga dapat mendorong peningkatan produksi mereka yang pada gilirannya berpengaruh terhadap pertumbuhan ekonomi di daerah. Namun demikian, pengaruh belanja sosial terhadap pertumbuhan ekonomi relatif lebih kecil dibandingkan dengan pengaruh belanja modal. Interpretasi ini didasarkan pada perbandingan nilai koefisien estimasi kedua jenis belanja. Peningkatan belanja sosial sebesar $1 \%$, berdampak pada kenaikan pertumbuhan ekonomi sebesar 0,089\%. Angka ini lebih kecil dibandingkan dampak belanja modal terhadap pertumbuhan, yakni sebesar 0,126\% untuk setiap $1 \%$ peningkatan belanja tersebut.

Adanya pengaruh positif dan signifikan belanja sosial terhadap pertumbuhan ekonomi daerah di Indonesia, konsisten dengan hasil penelitian Mayer et al. (2016) dan penelitian Amri (2020) yang juga membuktikan bahwa belanja hibah dan bantuan sosial dapat meningkatkan pendapatan masyarakat. Tetapi bertolak belakang dengan temuan Lukman et al. (2018) yang membuktikan bahwa layanan sosial dan masyarakat dan transfer pemerintah (recurrent expenditure) berpengaruh negatif tidak signifikan terhadap pertumbuhan ekonomi.

\section{Kesimpulan dan Implikasi}

Alokasi anggaran daerah dalam bentuk belanja modal dan belanja sosial diharapkan mampu mendorong pertumbuhan ekonomi daerah. Selama satu dekade terakhir, pertumbuhan ekonomi daerah di Indonesia relatif berbeda antara daerah yang satu dengan daerah lainnya. Dalam hal belanja modal dan belanja sosial, realisasi anggaran daerah untuk kedua jenis belanja ini juga relatif berbeda antar daerah. Karena itu, kajian ini mengeksplorasi pengaruh belanja modal dan belanja sosial terhadap pertumbuhan ekonomi daerah di Indonesia. Menggunakan data panel 24 provinsi selama periode 2005-2018, model analisis yang digunakan adalah regresi panel pendekatan fixed-effect.
Penelitian menyimpulkan bahwa belanja modal dan belanja sosial secara signifikan dapat mendorong pertumbuhan ekonomi daerah. Semakin besar realisasi anggaran daerah untuk penyediaan barang modal termasuk pembangunan instrastruktur fisik di daerah, dan semakin besar belanja sosial, semakin tinggi pertumbuhan. Sebaliknya penurunan kedua jenis belanja ini berdampak signifikan pada penurunan pertumbuhan ekonomi. Hal ini berimplikasi bahwa upaya peningkatan kesejahteraan masyarakat melalui kebijakan anggaran daerah dapat dilakukan dengan cara meningkatkan alokasi anggaran daerah dalam bentuk belanja modal dan belanja sosial.

\section{Daftar Pustaka}

Akhmad, Achsani, N. A., Tambunan, M., \& Mulyo, S. A. (2013). The impact of fiscal policy on the regional economy: Evidence from south Sulawesi, Indonesia, Journal of Applied Sciences Research, 9(4), 2463-2474.

Amri, K. (2014). Infrastruktur transportasi dan kepadatan penduduk dampaknya terhadap pendapatan per kapita: Panel data evidence dari sembilan provinsi di Sumatera. Jurnal Ekonomi Manajemen dan Bisnis, 2(2), 438-450.

Amri, K. (2020). Kebijakan fiskal dan pertumbuhan ekonomi daerah: Bukti data panel di Indonesia. Al-Masharif: Jurnal Ilmu Ekonomi dan Keislaman, 8(1), 1-18.

Amri, K., \& Adi, A. R. (2021). Pengaruh religiusitas keIslaman terhadap pertumbuhan ekonomi daerah: Bukti data panel kabupaten kota di Aceh, Jurnal Ilmiah Ekonomi dan Bisnis 18 (1), 29-28.

Amri, K., Nazamuddin, Masbar, R., \& Aimon, H. (2019). Is there a causality relationship between local tax revenue and regional economic growth? A panel data evidences from Indonesia. Regional Science Inquiry, 11 (1), 73-84. 
Bose, N., Hague, M.E., \& Osborn, D.R. (2007). Public expenditure and economic growth; A disaggregated analysis for developing countries. The Machester School, 75-85, 533-556. Boston: McGraw Hill Inc.

Chen, Z., Wang, Z., \& Jiang, H. (2019). Analyzing the heterogeneous impacts of high-speed rail entry on air travel in China: A hierarchical panel regression approach. Transportation Research Part A. Policy and Practice, 127, 86-98. doi:10.1016/j.tra.2019.07.004

Connolly, M., \& Li, C. (2016). Government spending and economic growth in the OECD countries. Journal of Economic Policy Reform, 19(4), 386-395. doi:10.1080/17487870.2016.12131

Ebaid, A., \& Bahari, Z. (2019). The nexus between government expenditure and economic growth: Evidence of the Wagner's Law in Kuwait. Review of Middle East Economics and Finance, 15(1). doi:10.1515/rmeef-2017-0001f.

Gregoriou, A., \& Ghosh, S. (2009). On the heterogeneous impact of public capital and current spending on growth across nations. Economics Letters, 105(1), 32-35. doi:10.1016/j.econlet.2009.05.009.

Guillaumont, J. S. \& Kpodar, K. (2011). Financial development and poverty reduction: Can there be a benefit without a cost? Journal of Development Studies, 47(1):143-163.

Gupta, S., Clements, B., Baldacci, E. and Mulas-Granados, C., (2005). Fiscal policy, expenditure composition, and growth in low-income countries. Journal of International Money and Finance, 24(3), 441-463.
Hasyim, S., Zulhilmi, M., \& Amri, K. (2019). Is there a causality relationship between law enforcement, crime rates, and economic growth? An empirical evidence from western Indonesia, Regional Science Inquiry 11 (3), 95-109.

Im, T., Cho, W., \& Porumbescu, G. (2011). An Empirical Analysis of the Relation Between Social Spending and Economic Growth in Developing Countries and OECD Members. Asia Pacific Journal of Public Administration, 33(1), 37-55. doi:10.1080/23276665.2011.1077

Lukman, A. F., Olukayode, A., Onate, C. A., Roseline, O. O., \& Babatunde, G. (2018). Data on expenditure, revenue, and economic growth in Nigeria. Data in Brief. doi:10.1016/j.dib.2018.08.191

Matthew, O., \& Udom, E. (2015). Estimating the impact of the components of public expenditure on economic growth in nigeria (a bound testing approach), International Journal of Economics, Commerce and Management, 3(3), 1-8.

Mayer, E., Ruth, S., \& Scharler, J. (2013). Government debt, inflation dynamics and the transmission of fiscal policy shocks, Economic Modelling 33, 762-771.

Modebe, N.J., Okafor, R. G., Onwumere, J. U. J., \& Ibe, I. G. (2012). Impact of recurrent and capital expenditure on Nigeria's economic growth, European Journal of Business and Management, 4(19), 66-74.

Morozumi, A., \& Veiga, F. J. (2016). Public spending and growth: The role of government accountability. European Economic Review, 89, 148-171. doi:10.1016/j.euroecorev.2016.07.001. 
Muda, I., \& Hutapea, A. A. F. (2018). Influence of capital expenditure and income original region to the income per capita in Indonesia. IOP Conf. Series: Earth and Environmental Science 126, doi:10.1088/1755-1315/126/1/012065.

Nazamuddin, B. S., \& Amri, K. (2020). Does goods and services spendings reduce income inequality? A panel data evidence from Indonesia, Regional Science Inquiry 12 (1), 87-102.

Obayori, J.B. (2016). Fiscal policy and unemployment in Nigeria. The International Journal of Social Sciences and Humanities Invention, 3(2), 1887-1891.

Pula, L., \& Elshani, A. (2018). Role of public expenditure in economic growth: Econometric evidence from Kosovo 2002-2015. Baltic Journal of Real Estate Economics and Construction Management, 6, 74-87 doi: 10. 2478/bjreecm-2018-0006.
Radulescu, M., Serbanescu, L., \& Sinisi, C. I. (2019). Consumption vs. Investments for stimulating economic growth and employment in the CEE Countries - a panel analysis. Economic ResearchEkonomska Istraživanja, 32(1), 2329-2353. doi:10.1080/1331677x.2019.16427.

Solomon, S., Bendickson, J. S., Liguori, E. W., \& Marvel, M. R. (2021). The effects of social spending on entrepreneurship in developed nations. Small Business Economics. doi:10.1007/s11187-02100458-9. 